\title{
TRANSFORMASI LINIER DALAM GAME ANIMASI UNTUK PEMBELAJARAN PERSAMAAN KURVA
}

\author{
Nugroho Agus Haryono, Hendro Setiadi, Setiawan \\ Fakultas Teknik Program Studi Teknik Informatika \\ Universitas Kristen Duta Wacana Yogyakarta \\ Email: cnug@ukdw.ac.id, setiadi.hendro@gmail.com, setiawan.aliong@gmail.com
}

\begin{abstract}
Abstrak :
Media visual menjadi salah satu daya tarik tersendiri sebagai media pembelajaran. Dengan adanya media visual, suasana belajar menjadi menyenangkan dan pelajar tentunya akan lebih mudah mengerti. Salah satu media visual yang dapat digunakan adalah permainan berbasis komputer atau yang lebih dikenal dengan istilah game. Game sebagai media visual memiliki kelebihan dibanding dengan media visual yang lain karena game mengajak pemainnya untuk turut serta dan andil dalam menentukan hasil akhir dari game tersebut.

Dalam tulisan ini dibahas hasil pembuatan game 2 dimensi yang dapat menampilkan visualisasi pergerakan objek mengikuti sebuah persamaan kurva dengan menggunakan metode transformasi linier. Game yang dibuat terdiri dari 3 level yaitu level pertama berupa game penentuan persamaan garis lurus, level kedua berupa game penentuan persamaan kurva sinus, dan level ketiga berupa game penentuan persamaan kurva cosinus. Masing-masing tahap mempunyai 10 sublevel yang harus diselesaikan untuk dapat menuju level berikutnya.

Dari hasil penerapan metode transformasi linier dalam game ini diketahui bahwa kecekungan persamaan kurva mempengaruhi kecepatan pergerakan animasi objek yang mengikuti persamaan kurva tersebut. Semakin cekung persamaan kurva, semakin bertambah cepat pergerakan objek tersebut.
\end{abstract}

Kata Kunci : Game, transformasi linier, animasi, persamaan kurva

\section{Pendahuluan}

Saat ini, perkembangan teknologi terutama di bidang teknologi informasi sangat pesat. Berkembangnya teknologi informasi mendorong perkembangan sarana pembelajaran di berbagai bidang ilmu pengetahuan. Media yang digunakan sebagai sarana pembelajaran beraneka ragam, misalnya pembelajaran dengan metode konvensional seperti membaca buku dan mengerjakan latihan, sampai dengan metode pembelajaran yang interaktif dan tidak membosankan, yakni menggunakan media visual. Media visual menjadi salah satu daya tarik tersendiri sebagai media pembelajaran. Dengan adanya media visual, suasana belajar menjadi 
menyenangkan dan pelajar tentunya akan lebih mudah mengerti.

Salah satu media visual yang dapat digunakan adalah permainan berbasis komputer atau yang lebih dikenal dengan istilah game. Game sebagai media visual memiliki kelebihan dibanding dengan media visual yang lain karena game mengajak pemainnya untuk turut serta dan andil dalam menentukan hasil akhir dari game tersebut.

\section{Game}

Menurut Ernest Adams dan Andrew Rollings (2007) dalam buku Fundamentals of Game Design, game meruapakan salah satu jenis kegiatan bermain dengan pemainnya berusaha meraih tujuan dari game tersebut dengan melakukan aksi sesuai dengan aturan dari game tersebut.

\subsection{Game Design}

Menurut Ernest Adams dan Andrew Rollings (2007) dalam buku Fundamentals of Game Design, sebuah game memiiki beberapa elemen dasar yaitu core mechanics, user interface, dan gameplay. Skema komponen game design diberikan dalam Gambar 1.

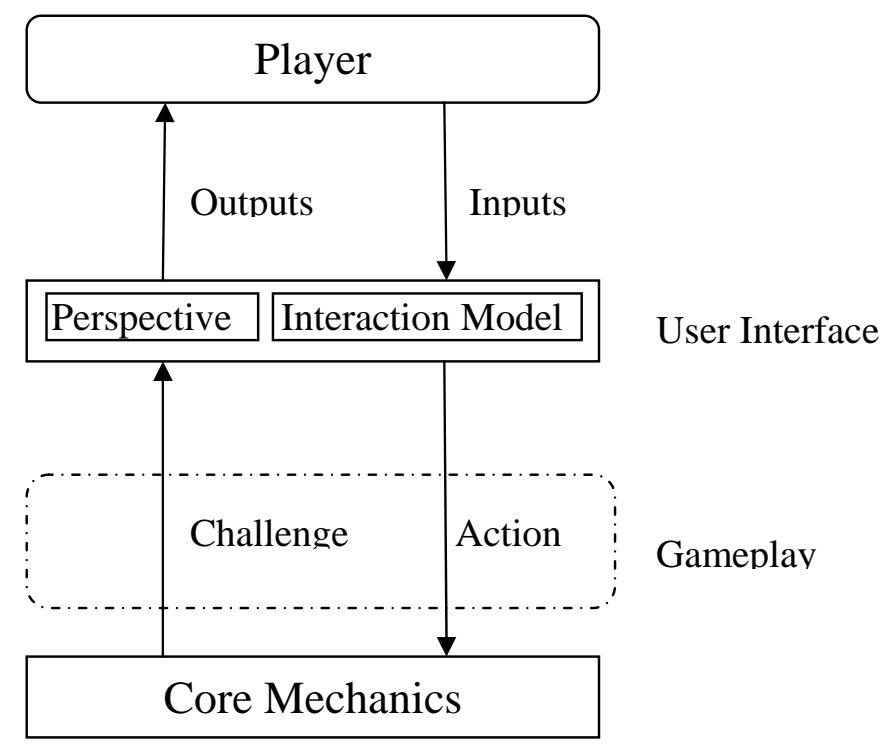

Gambar 1. Komponen Game Design (Adams dan Rollings, 2007:46)

\section{Core Mechanics}

Core mechanics menurut Adams dan Rollings (2006:43), adalah suatu model yang menjelaskan rules dari game secara spesifik dengan menggunakan simbol-simbol matematika. Core mechanics menjelaskan bagaimana cara kerja game, rules dari game, bagaimana pemain 
berinteraksi dengan game, bagaimana kondisi untuk mencapai goal dari sebuah game. Secara lebih mendalam, beberapa fungsi dari core mechanics adalah sebagai berikut :

a. Core mechanics menjelaskan mengenai syarat dan kondisi mengenai keberadaan pemain, apakah pemain masih bisa meneruskan permainan, ataukah pemain tidak dapat melanjutkan permainan.

b. Memberikan challenge (tantangan) kepada pemain

c. Menerima input dari pemain

d. Mengubah mode game dari satu mode ke mode yang lain. Saat terjadi perubahan mode, game akan memberi informasi kepada pemain. Informasi yang dapat diterima antara lain terjadinya perubahan user interface dan suara latar.

\section{User Interface}

User interface menghubungkan antara pemain dengan core mechanics. User interface pada game berbeda dengan user interface pada software-software komputer pada umumnya. User interface pada game dapat juga menjadi challenges dari game tersebut.

Beberapa konsep yang digunakan untuk mendesain user interface antara lain:

a. Perlu adanya konsistensi.

b. User interface memberikan feedback yang tepat kepada pemain.

c. Pemain adalah pemegang kontrol utama dalam game. Pemain mengharapkan apa yang dikirim ke sistem memberikan feedback sesuai apa yang diharapkan.

d. Pembatasan pada user interface sangat diperlukan karena game mempunyai banya aturan (rule).

\section{Gameplay}

Gameplay adalah rangkaian dari challenges dan actions yang menghubungkan antara user interface dengan core mechanics dari game.

\section{Challenges (Tantangan)}

Tantangan adalah serangkaian tantangan yang harus diselesaikan oleh pemain untuk mencapai tujuan dari game tersebut. Tantangan yang ada dalam game dibagi menjadi dua jenis yaitu tantangan implisit dan tantangan eksplisit.

\section{Actions (Aksi)}

Aksi adalah serangkai inputan dari user melalui user interface untuk menghadapi challenges yang diberikan oleh game agar mencapai tujuan dari game tersebut. Aksi ini yang menghubungkan antara user interface dengan core mechanics. 


\subsection{Deteksi Tumbukan (Collision Detection)}

Menurut Keith Peters (2007) dalam buku Foundation ActionScript 3.0 Animation, Making Things Move!, setiap objek memiliki kotak yang mengelilinginya, itulah yang disebut dengan bounding box. Dalam lingkungan flash, terdapat dua macam tumbukan yaitu tumbukan berdasarkan bounding box dan tumbukan secara titik koordinat. Pada tumbukan berdasarkan bounding box, ketika bounding box suatu objek bertumbukan dengan bounding box objek lain maka kedua objek tersebut dikatakan bertumbukan. Dalam hal ini, penulis menggunakan bounding box untuk pembuatan game. Contoh tumbukan objek menggunakan bounding box diberikan dalam Gambar 2.

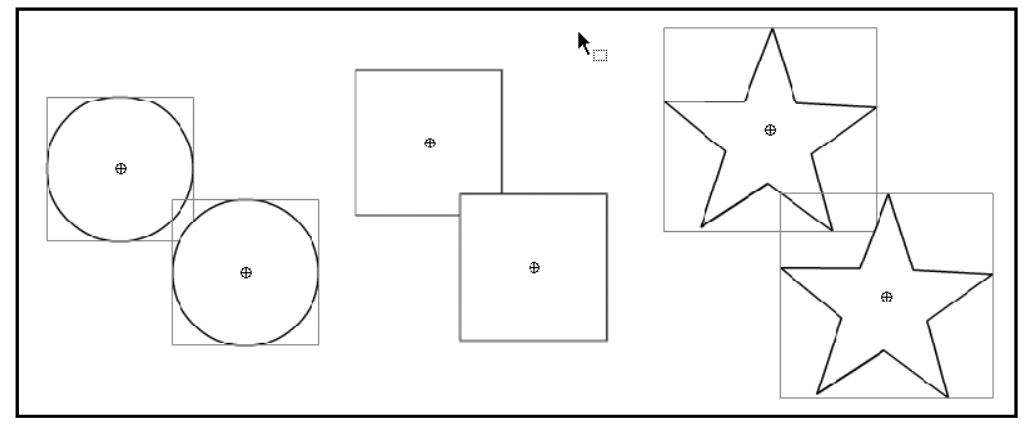

Gambar 2. Objek Bertumbukan

\subsection{ActionScript 3.0}

Dalam pembuatan game, penulis menggunakan ActionScript 3.0 sebagai bahasa scripting untuk pengembangan aplikasi dalam Flash. Keuntungan menggunakan ActionScript adalah kita dapat menambah fungsi yang kompleks yang tidak dapat dilakukan jika menggunakan timeline sehingga aplikasi kita tidak statik.

\section{Implementasi dan Pembahasan}

\subsection{Tampilan Menu Utama}

Tampilan menu utama dalam game ini berupa halaman yang bagian atas seperti papan tulis dan bagian bawah seperti meja belajar. Di atas meja belajar terdapat tulisan Game Edukasi Persamaan Garis dan 3 tombol untuk memilih menu. Tampilan awal game diberikan dalam Gambar 3. 


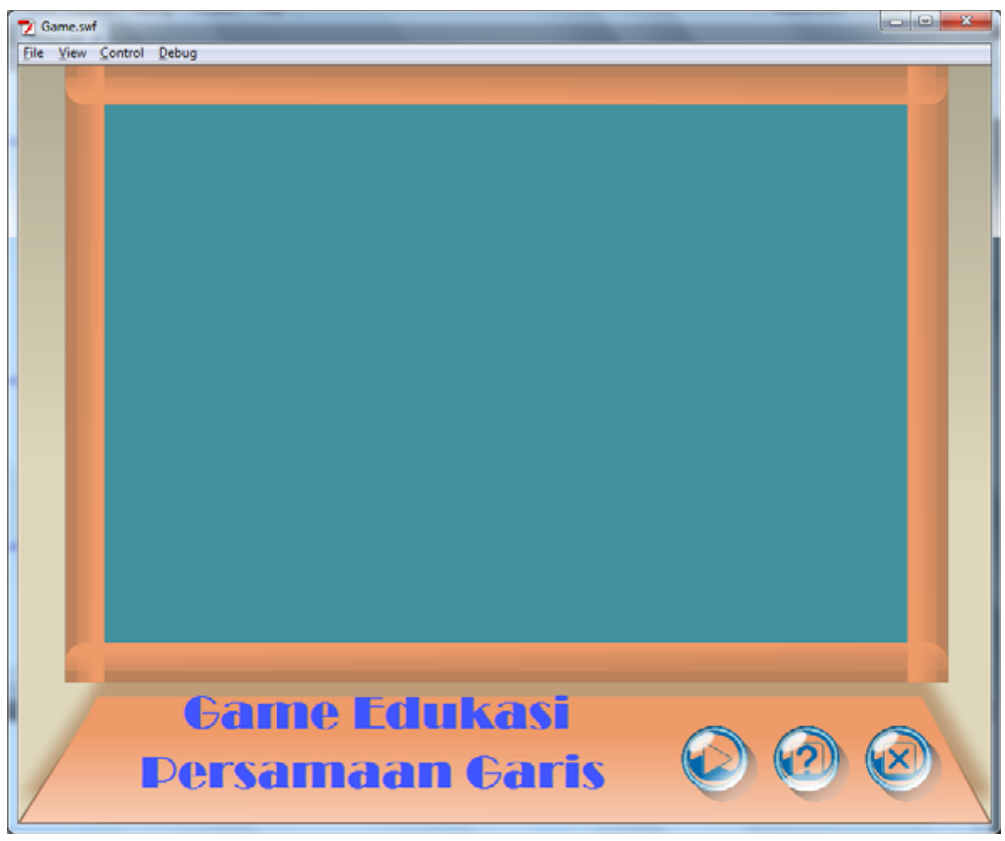

Gambar 3. Halaman Utama

Berikut ini diberikan fungsi-fungsi Ketiga tombol yang ada dalam menu utama.

- Tombol digunakan untuk memulai permainan.

- Tombol sebagai fungsi bantuan, digunakan untuk melihat cara main, belajar persamaan garis menggunakan simulasi, belajar persamaan garis menggunakan visualisasi, dan belajar persamaan garis melalui tutorial yang disediakan.

- Tombol digunakan untuk keluar dari sistem.

\subsection{Area Utama Permainan}

Persamaan garis terletak pada koordinat kartesius yang terdiri dari 4 kuadran yaitu kuadran I, II, III, dan IV. Permainan ini menitikberatkan pada visualisasi persamaan garis tersebut sehingga perlu dibuat koordinat kartesius 4 kuadran. Titik pusat koordinat $(0,0)$ pada Koordinat Kartesius diletakkan pada koordinat $(451,286)$ pada lingkungan flash. Skala jarak dalam sumbu-X dibuat sama dengan skala jarak dalam sumbu-Y. Batas daerah utama game (berupa papan tulis) memiliki batas atas kiri $(80,36)$ dan batas bawah kanan $(822,532)$. Posisiposisi koordinat tersebut dibuat tetap dalam lingkungan flash. Pembuatan koordinat kartesian dalam daerah utama game diberikan dalam Gambar 4 . 


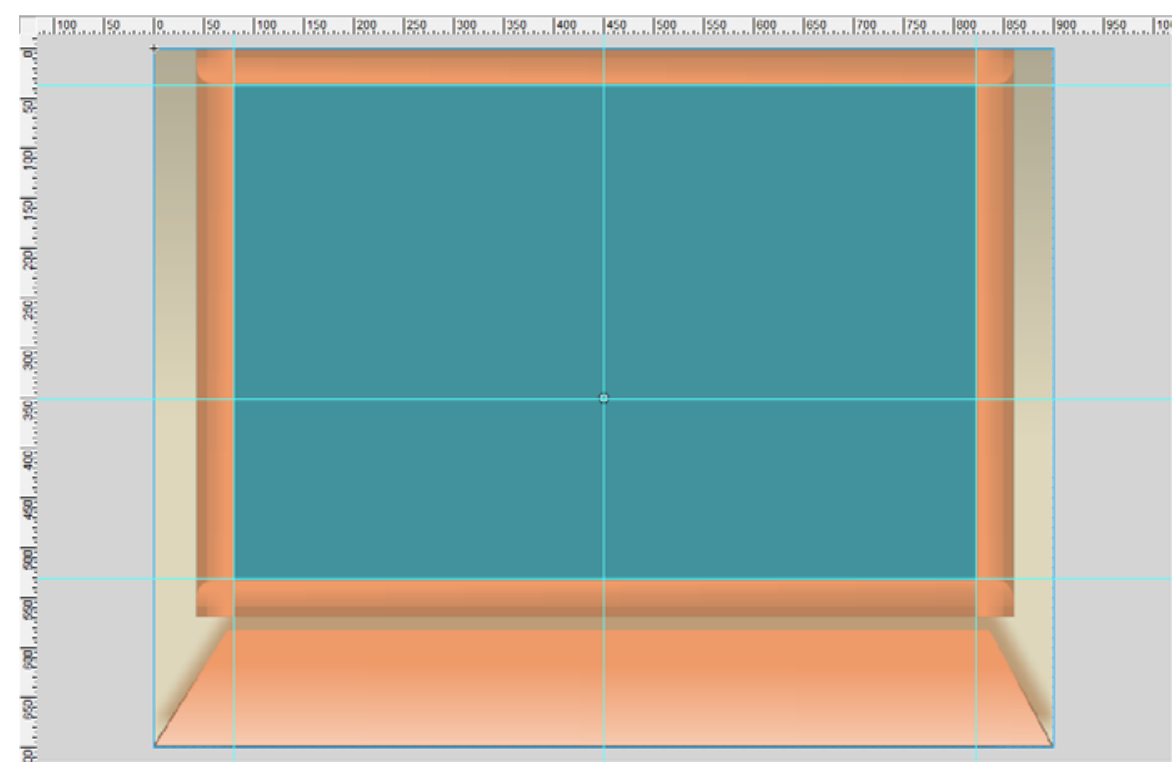

Gambar 4. Gambar Penentuan Daerah Utama Game

\subsection{Penerapan Transformasi Linier}

\section{Translasi}

Dalam game ini, penerapan translasi terlihat pada pergerak objek saat mengikuti visualisasi dari persamaan garis. Objek selalu bergerak mengikuti koordinat $(x, y)$ dengan $x$ dibuat dari kiri bergerak ke kanan (semakin besar), dan y menyesuaikan hasil fungsi terhadap nilai $x$. Proses translasi objek diberikan dalam script berikut ini.

$$
\begin{aligned}
& \text { xLama = objek.x; } \\
& \text { xBaru = xLama }+2 ; \\
& \text { yBaru = fungsi }(x B a r u) ; \\
& \text { objek.x = xBaru; } \\
& \text { objek.y = yBaru; }
\end{aligned}
$$

\section{Dilatasi}

Dalam game ini, penerapan dilatasi terlihat pada animasi tembakan saat mengenai dinding batas flash. Tembakan yang berupa bola saat mengenai dinding flash, tembakan tidak akan bergerak ke kanan maupun ke kiri, tembakan tersebut hanya akan mengecil sampai pada batas tertentu, tembakan tersebut menghilang. Proses dilatasi objek diberikan dalam script berikut ini. 


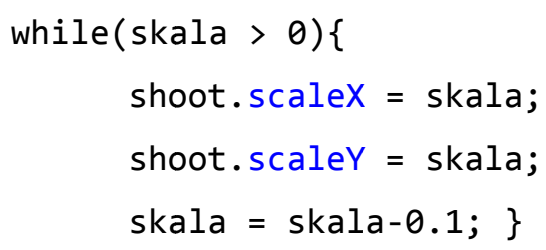

\section{Rotasi}

Dalam game ini, rotasi diterapkan ketika objek berjalan mengikuti persamaan sebuah kurva yang melengkung sehingga animasi pergerakan objek akan tampak seperti mengikuti lintasan. Contoh penggunaan rotasi pada objek diberikan dalam Gambar 5.
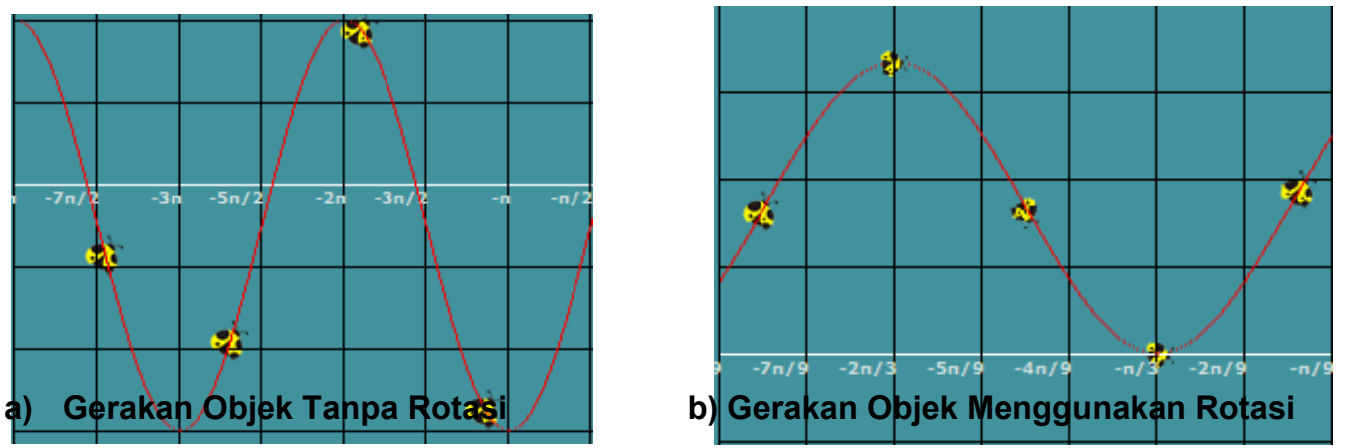

\section{Gambar 5. Penggunaan rotasi pada objek}

Mencari sudut pergerakan objek dari sebuah titik ke titik lain dapat digambarkan sebagai berikut :

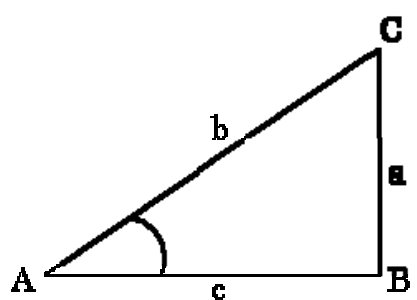

Objek mula-mula berada di A kemudian bergerak menuju C. Sudut A adalah sudut pergerakan objek tersebut. $\tan \alpha=\mathbf{a} / \mathbf{c}$ atau jika $A$ terletak pada $\left(\mathbf{x}_{0}, \mathbf{y}_{\mathbf{0}}\right)$ dan $C$ terletak pada $\left(\mathbf{x}_{1}, \mathbf{y}_{1}\right)$ maka $\tan \mathbf{A}=\left(\mathbf{y}_{1}-\mathbf{y}_{0}\right) /\left(\mathbf{x}_{1}-\mathbf{x}_{0}\right)$. Untuk mencari sudut $\mathbf{\alpha}$ dapat dihitung dengan menggunakan rumus $\alpha=\operatorname{arc} \tan \left(\mathbf{y}_{1}-\mathbf{y}_{0}\right) /\left(\mathbf{x}_{1}-\mathbf{x}_{0}\right)$. Proses rotasi objek diberikan dalam script berikut ini.

sudut $=$ Math $\cdot \operatorname{atan2}(($ posisiY-yLama $),($ posisiX $-X L a m a)) ;$

objek.rotation=PUSAT_ROTASI+sudut*180/Math.PI; 


\subsection{Model level permainan}

Game yang dibuat terdiri dari 3 level yaitu level pertama berupa game penentuan persamaan garis lurus, level kedua berupa game penentuan persamaan kurva sinus, dan level ketiga berupa game penentuan persamaan kurva cosinus. Masing-masing tahap mempunyai 10 sublevel yang harus diselesaikan untuk dapat menuju level berikutnya.

Pada level satu, dibuat sebuah fungsi yang dapat menerima dua masukan dua paramater $\mathrm{m}$ (gradien) dan $\mathrm{c}$ (perpotongan dengan sumbu y). Berikutnya dibuat visualisasi garis persamaan fungsi $\mathrm{y}=\mathrm{mx}+\mathrm{c}$, yang diikuti oleh pergerakan objek-objek (berupa serangga) sesuai garis tersebut. Objek-objek akan bergerak dari kiri ke kanan sampai keluar batas area utama game.

Pada level dua, dibuat sebuah fungsi yang dapat menerima tiga masukan parameter $a, b$, dan $c$ untuk membentuk persamaan $y=a+b \cdot \sin c x$. Berikutnya dibuat visualisasi kurva dari persamaan tersebut. yang diikuti oleh pergerakan objek-objek (berupa serangga) sesuai kurva tersebut. Objek-objek akan bergerak dari kiri ke kanan sampai keluar batas area utama game.

Pada level dua, dibuat sebuah fungsi yang dapat menerima tiga masukan parameter $a, b$, dan $c$ untuk membentuk persamaan $y=a+b \cdot c o s c x$. Berikutnya dibuat visualisasi kurva dari persamaan tersebut. yang diikuti oleh pergerakan objek-objek (berupa serangga) sesuai kurva tersebut. Objek-objek akan bergerak dari kiri ke kanan sampai keluar batas area utama game.

Dalam visualisasi kurva sinus dan kurva cosinus digunakan Gambar 6 dan perhitungan berikut ini.

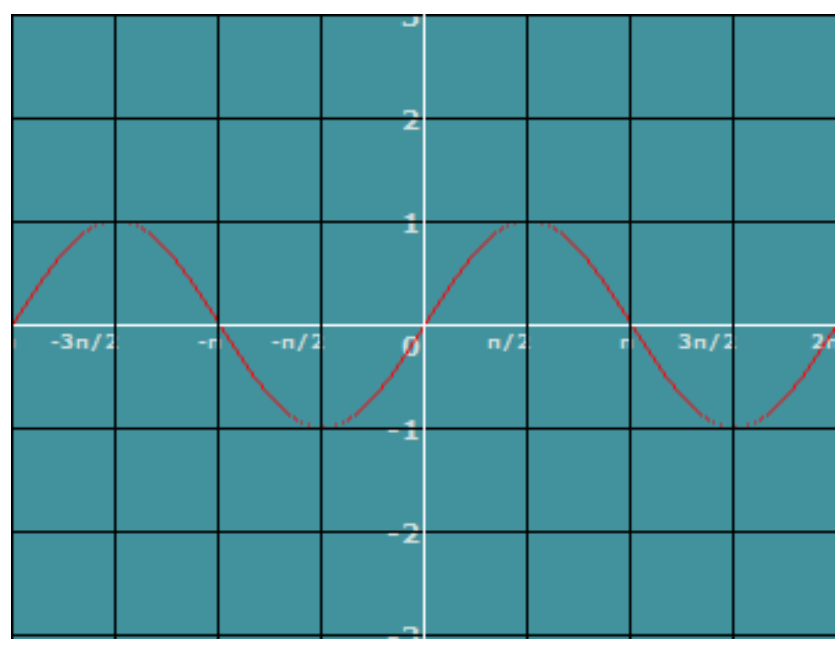

Nilai maksimum

Interval $Y$

Titik pusat

Batas tengah

Nilai minimum

Gambar 6. Kurva $y=\sin x$

Persamaan $\mathbf{y}=\mathbf{a}+\mathbf{b} \sin \mathbf{c x}$ mempunyai nilai minimum pada $\mathbf{m i n}=\mathbf{a}-\mathbf{b}$ dan akan mencapai nilai maksimum pada maks=a+b. Batas tengah dari kurva diambil dari batasTengah $=(\min +\operatorname{maks}) / \mathbf{2}=((\mathrm{a}-\mathrm{b})+(\mathrm{a}+\mathrm{b})) / \mathbf{2}=\mathbf{2} \mathbf{a} / \mathbf{2}=\mathbf{a}$. Batas tengah pada lingkungan flash dapat diperoleh dengan menggunakan rumus: 


\section{batasTengahY=titikPusatY- (a*intervalY)}

Nilai b digunakan untuk menentukan besarnya skala visualisasi pada sumbu-Y. Nilai c digunakan untuk menentukan besarnya skala visualisasi pada sumbu- $X$

\subsection{Deteksi Tumbukan (Collision Detection)}

Dalam game ini terdapat 3 tumbukan yaitu :

a. Tumbukan tembakan dengan objek

Untuk mendeteksi tumbukan antara objek serangga dengan objek tembakan (peluru kendali) digunakan fungsi hitTestObject(), bawanaan ActionScript 3.0. Setiap kali tembakan berhasil mengenai objek serangga, maka objek serangga tersebut akan menghilang dan nilai pemain bertambah. Proses deteksi tumbukan antar objek diberikan berikut ini.

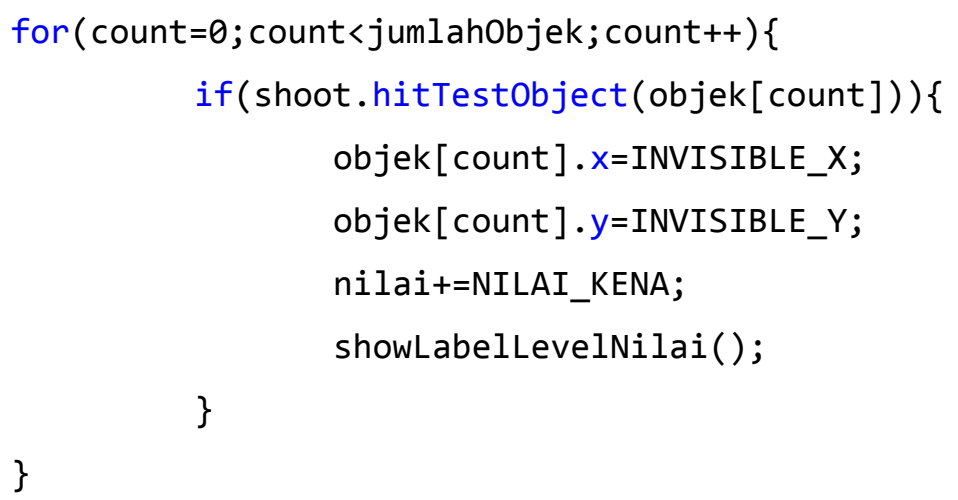

b. Tumbukan objek dengan batas area permainan

Tumbukan antara objek serangga atau pun tembakan dengan batas area permainan tidak digunakan fungsi hitTestObject(), namun hanya menggunakan deteksi koordinat objek. Jika koordinat objek sudah melebihi batas area game, maka objek akan menghilang. Apabila objek serangga mencapai batas area game sebelum tertembak maka nilai pemain akan berkurang. Proses pendeteksian pencapaian batas area diberikan berikut ini.

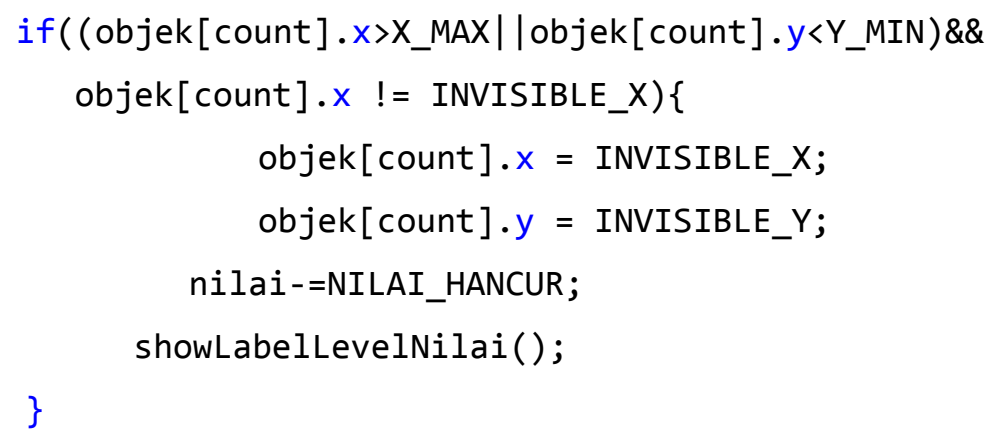




\section{Analisis Kelebihan dan Kekurangan Game}

Setelah menerapkan transformasi linier, ditemukan beberapa kelebihan game yang dibuat sebagai berikut:

- Game dapat mengacak nilai-nilai koefisien dan konstanta dari persamaan garis yang akan ditampilkan sehingga pemain akan merasa tidak bosan.

- Game dapat mengubah nilai pada interval titik koordinat sesuai dengan persamaan garis yang dibangkitkan oleh sistem sehingga pemain tidak akan merasa kesulitan menghitung persamaan yang dimaksud oleh sistem.

- Game dapat mengacak nilai pada interval titik koordinat namun tetap sesuai dengan persamaan yang dibangkitkan oleh sistem sehingga pemain akan jarang menemukan jenis persamaan yang sama.

- Game dapat memberikan waktu yang tidak jauh berbeda meskipun persamaan yang ditampilkan berbeda.

- Game dapat memberikan nilai jika pemain dapat menyelesaikan permaianan sebelum batas waktu yang ditentukan selesai.

- Game memberikan pembelajaran melalui visualisasi sehingga pemain dapat melatih menebak persamaan sebelum memainkan game.

- Game memberikan pembelajaran melalui simulasi sehingga pemain dapat mencoba-coba memasukkan input nilai ke dalam persamaan dan mengamati grafik persamaan yang terbentuk.

- Game memberikan pembelajaran melalui tutorial secara tertulis sehingga pemain dapat mempelajari materi persamaan yang akan dimainkan.

Sedangkan kekurangan dalam game ini adalah sebagai berikut :

- Game hanya dapat menentukan waktu pergerakan animasi dengan tingkat akurasi 1 detik sehingga terdapat perbedaan kecepatan pergerakan animasi saat objek yang muncul sudah banyak.

- Beberapa pergerakan animasi objek terlihat kurang halus terutama jika waktu delay objek dibuat terlalu tinggi.

\section{Kesimpulan dan Saran}

Setelah dilakukan penelitian berdasarkan program yang dibuat, disimpulkan bahwa metode transformasi linier dapat diterapkan dalam pembuatan game animasi persamaan kurva. Game dapat mengacak nilai-nilai koefisien dan konstanta dari persamaan garis serta mengubah nilai pada interval titik-titik koordinat sesuai dengan persamaan garis tersebut.

Dari penelitian ini juga diketahui bahwa kecekungan persamaan kurva mempengaruhi 
kecepatan animasi objek yang mengikuti persamaan kurva tersebut. Semakin cekung persamaan kurva, semakin bertambah cepat pergerakan objek tersebut meskipun penulis telah meneliti bahwa waktu yang ditempuh oleh objek akan selalu sama dari awal objek muncul sampai objek menumbuk batas area permainan.

Pembuatan game edukasi ini juga menyertakan cara edukasi lain yaitu pembuatan visualisasi persamaan garis, pembuatan simulasi persamaan garis, dan pemberian tutorial sederhana bagi pemain sebelum memainkan game ini.

Rumusan sistem ini dapat dikembangkan lebih lanjut dengan menerapkan konsep desain interaksi yang lebih baik melalui survey kepada pemain. Sistem juga akan menjadi lebih kompleks jika sistem memberikan tantangan yang lebih banyak. Pengembangan sistem ini juga dapat dilakukan dengan menambah materi pembelajaran pada game misalnya dengan menambahkan pembelajaran persamaan kuadrat atau persamaan parabola.

\section{Daftar Pustaka}

[1] Adams, Ernest., \& Andrew Rollings. (2007). Fundamentals of Game Design. New Jersey: Pearson Education, Inc.

[2] Alexander, Bryan. (2008, July/August). Games for Education: 2008. Educause Review. hlm 64.

[3] Andre Lamothe. (2004). Mathematics For Game Developer. Thomson Course Technology.

[4] Peters, Keith. (2006). Foundation ActionScript Animation: Making Things Move!. New York: Springer-Verlag New York, Inc.

[5] Virvou, M., Katsionis, G., \& Manos, K. (2005). Combining Software Games with Education: Evaluation of its Educational Effectiveness. Educational Technology \& Society, 8 (2), 54-65. 